\title{
Preoperative descriptive upper airway assessment in craniomaxillofacial tumor
}

\author{
Avaliação descritiva pré-operatória das vias aéreas superiores em tumor craniomaxilofacial \\ Evaluación descriptive preoperatoria de la vía aérea superior en tumor craneomaxilofacial
}

Received: 04/24/2021 | Reviewed: 05/03/2021 | Accept: 05/06/2021 | Published: 05/21/2021

\author{
Maísa Pereira da Silva \\ ORCID: https://orcid.org/0000-0003-2483-8695 \\ Clinical Hospital of Federal University of Minas Gerais, Brazil \\ E-mail: maisaodonto1@gmail.com \\ Felipe Eduardo Baires Campos \\ ORCID: https://orcid.org/0000-0001-7781-3737 \\ Clinical Hospital of Federal University of Minas Gerais, Brazil \\ E-mail: felipebaires@hotmail.com \\ Guilherme de Souza Silva \\ ORCID: https://orcid.org/0000-0003-0901-8728 \\ Clinical Hospital of Federal University of Minas Gerais, Brazil \\ E-mail: guilhermeccpbh@gmail.com \\ Wagner Henriques de Castro \\ ORCID: https://orcid.org/0000-0003-2745-2878 \\ Clinical Hospital of Federal University of Minas Gerais, Brazil \\ E-mail:wagnerhcastro@hotmail.com
}

\begin{abstract}
Giant osteoma appears as a benign nonodontogenic tumor of craniofacial and jaw bones with potential growth. This type of tumor affects different maxillofacial regions, thus requiring proper planning to resolve the patient's esthetic and/or functional complaints. Medial impairment of the mandible can compromise upper airway (UA) dimensions, leading to respiratory disorders. However, to date, there is a lack of information in the literature about 3D UA imaging protocols for surgical planning. Accurate evaluation, elucidating the involvement of the upper airway patency, may demonstrate the need and urgency for surgical intervention. Therefore, our study aim report a case of a giant mandibular osteoma, associated with a sudden constriction of the oropharyngeal space that was assessed by a Computer Software. The UA was assessed all dimensions, and determining the surgical procedure. In follow up could observed an improvement of UA and patient complain. This study emphasizes the importance of the detailed preoperative assessment of giant osteoma to determinate the correct approach.
\end{abstract}

Keywords: Osteoma; Software; Constriction; Growth; Therapeutics.

\section{Resumo}

O osteoma gigantiforme é um tumor benigno não odontogênico dos ossos craniomaxilofaciais com potencial de crescimento. Este tipo de tumor atinge diferentes regiões maxilofaciais, exigindo um planejamento adequado para o tratamento das queixas estéticas e /ou funcionais do paciente. O acometimento medial da mandíbula pelo osteoma pode comprometer as dimensões das vias aéreas superiores (VAS), levando a distúrbios respiratórios. No entanto, até o momento, faltam informações na literatura sobre os protocolos de imagem tridimensional das VAS para o planejamento cirúrgico. A avaliação precisa, elucidando o envolvimento da patência das vias aéreas superiores, pode demonstrar a necessidade e urgência da intervenção cirúrgica. Portanto, nosso estudo tem como objetivo relatar um caso de osteoma gigantiforme, associado a uma constrição súbita do espaço orofaríngeo que foi avaliado por um software. A VAS foi avaliada em todas as dimensões, determinando o procedimento cirúrgico. No acompanhamento pós-operatório observamos melhora da VAS e das queixas dos pacientes. Este estudo enfatizou a importância da avaliação pré-operatória detalhada do osteoma gigantiforme para determinar a abordagem adequada.

Palavras-chave: Osteoma; Software; Constrição; Crescimento; Terapêutica.

\section{Resumen}

Osteoma gigante és un tumor benigno no odontogénico de huesos craneofaciales y maxilares con crecimiento potencial. Este tipo de tumor afecta las diferentes regiones maxilofaciales, por lo que requiere una planificación adecuada para resolver las quejas estéticas y / o funcionales del paciente. La alteración medial de la mandíbula puede comprometer las dimensiones de las vías respiratorias superiores (VRS) y provocar trastornos respiratorios. Sin embargo, hasta el momento, hay una falta de información en la literatura sobre los protocolos de imagenología 3D VRS para la planificación quirúrgica. Una evaluación precisa, que aclare la afectación de la permeabilidad de las vías respiratorias superiores, puede demostrar la necesidad y urgencia de una intervención quirúrgica. Por tanto, el objetivo de nuestro estudio es reportar un caso de osteoma mandibular gigante, asociado a una súbita constricción del espacio 
orofaríngeo que fue evaluado por un software. Se evaluó la VRS en todas las dimensiones y se determinó el procedimiento quirúrgico. En el seguimiento se pudo observar una mejoría de la VRS y los pacientes se quejaron. Este estudio enfatiza la importancia de la evaluación preoperatoria detallada de osteoma mandibular gigante para determinar el abordaje correcto.

Palabras clave: Osteoma; Programas informáticos; Constricción; Crecimiento; Terapéutica.

\section{Introduction}

Osteoma appears as a relatively rare benign nonodontogenic tumor of the craniofacial and jaw bones (Regezi et al., 2003). Its histopathology is characterized by a lamellar or cancellous bone presence, and the osseous formation can be central, peripheral, or extraskeletal (Regezi et al., 2003; Neville et al., 2009; Lekas et al., 2009). Peripheral osteomas are defined by centrifugal growth from the periosteum, while central osteomas present centripetal progression from the endosteum (Sayan et al., 2002; Hitchin \& White, 1955). The pathogenesis of peripheral osteoma is unclear and has been considered a neoplasm (Regezi et al., 2003; Neville et al., 2009; Sayan et al., 2002). However, the reactive mechanism due to trauma, infection, and muscle activity can also initiate an osteogenic reaction. (Regezi et al., 2003; Sayan et al., 2002; Cutilli \& Quinn, 1992; Ma'luf et al., 2003; Bodner et al., 1998).

Most osteomas consist of small lesions; however, wider tumors can occur with a diameter of more than 30mm, which are classified as giant osteomas (Fobe et al., 2002; Izci, 2005). Clinical aspects are normally related to growth extension, which can produce facial asymmetry,as well as respiratory and swallowing dysfunctions caused by direct interference in their anatomic location (Sadeghi et al., 2015; Almeida \& de Oliveira Filho, 2011; Tarsitano \& Marchetti, 2013).

Giant osteoma treatment can be conducted by a conservative approach or with surgical management (Neville et al., 2009; Sadeghi et al., 2015; Ata-Ali \& Ata-Ali, 2019) The current literature available to make this decision is scarce regarding the need for a dimensional assessment of the upper airway (UA). The relevance of this analysis is that bone mass growth can decrease the total airway volume and the maximum constriction area (MCA) (Tarsitano \& Marchetti, 2013). This paper reports on a case of giant mandibular osteoma, associated with an sudden oropharyngeal space constriction, which was diagnosed and planned by an computer-aided surgical simulation.

\section{Methodology}

The present study consist of the a case report of a patient evaluated in Clinical Hospital of Federal University of Minas Gerais, that presented a benign nonodontogenic tumor of craniofacial and jaw bones leading to a compromise upper airway (UA) dimensions, thus requiring proper assessment. In this study was applied the methodology as previously described (Pereira et al, 2018), it being characterized as a descriptive and qualitative study. The Free and Clarified Term Consent was applied.

\section{Case Report}

A 51-year-old female was referred to the oral and maxillofacial surgery service of the Clinical Hospital of the Federal University of Minas Gerais (Belo Horizonte, Brazil), in November 2017, complaining of facial asymmetry and pain in the cervico-facial region. The patient reported that, 14 years prior, in another healthcare center, she had been diagnosed with the presence of a mandibular osteoma. At that time, she declined any source of surgical treatment for personal reasons. Conservative management was therefore implemented, with periodic clinical and cone-beam computed tomography (CBCT) controls. Since then, a slow-growing mass and expansive swelling was clinically observed in the left submandibular and mandibular ramus region, leading to facial asymmetry. 
Comparing preoperative CBCT with another taken after a two-year interval, a severe constriction was verified in the oropharynx and hypopharynx regions. This finding may well be related to a lateral pharyngeal wall displacement in the medial and posterior directions due to a progressive growth in bone mass. UA assessment was performed with Dolphin Imaging® (Dolphin Imaging \& Management Solutions, Chatsworth, CA), using the sinus/airway tool as previously described (Dos Santos et al., 2020). The CBCT was positioned according to reference planes and landmarks. The UA region was then delineated according to the following limits: a) superior limit - line extending from the odontoid process to the posterior nasal spine (PNS); b) anterior limit - line extending from PNS, soft palate, posterior dorsum of the tongue to the bone hyoid; c) inferior limit - line from bone hyoid to the posterosuperior corner of cervical vertebra 3 (CV3); and d) posterior limit - line from $\mathrm{CV} 3$ to the upper cervical vertebra 2 (CV2) and odontoid process. (Figure 1)

Figure 1. Upper airway boundaries and landmarks that were performed in software Dolphin Imaging® and highlight the UA and its interruption in sagittal view.

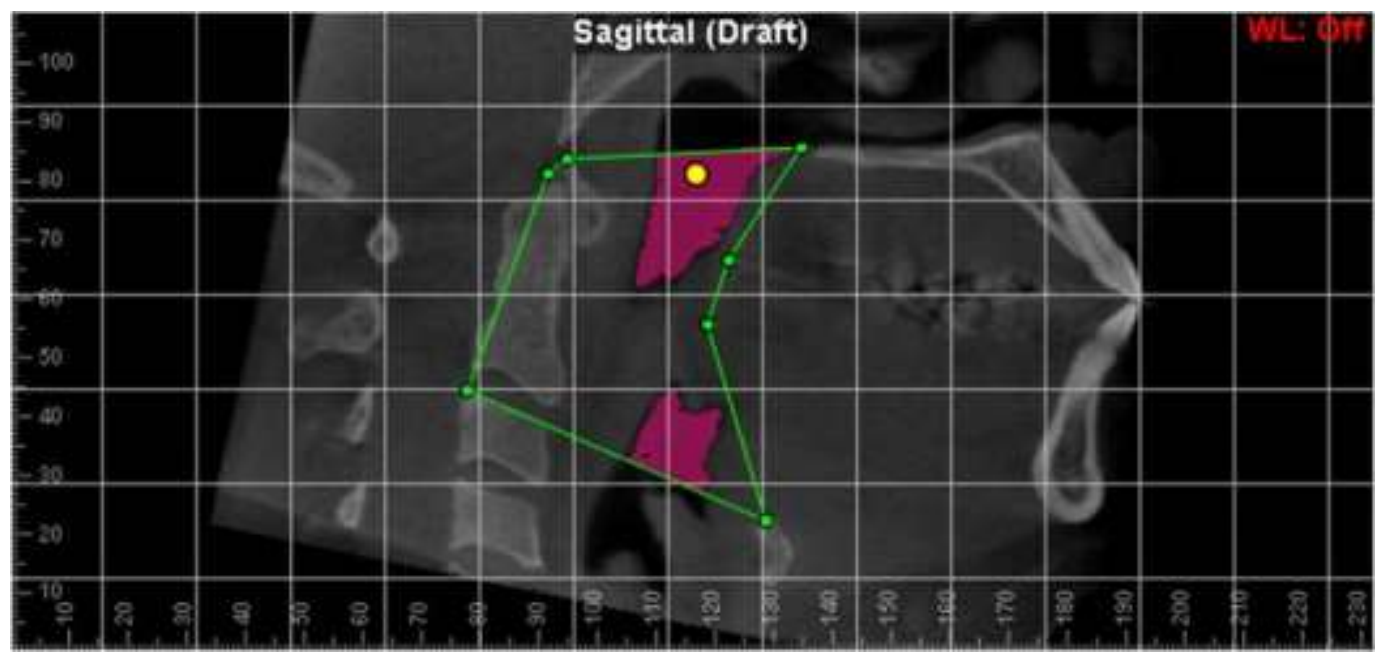

Source: Own authorship.

Quantitative airway analyses were assessed at different moments before surgery and demonstrated a decrease of $40 \%$ in MCA and of $28 \%$ in the airway area evaluation (Table 1).

Table 1. Upper airway pharyngeal assessment shows the decrease the MCA, airway area and volume in two years, and the increase after treatment.

Table 1. Upper airway pharyngeal assessment.

\begin{tabular}{ccccc}
\hline Year & & MCA & Airway Area & Airway Volume \\
\hline 2018 & Preoperative & $75 \mathrm{~mm}$ & $172 \mathrm{~mm}^{2}$ & $9160 \mathrm{~mm}^{3}$ \\
2020 & Preoperative & $26 \mathrm{~mm}$ & $124 \mathrm{~mm}^{2}$ & $9069 \mathrm{~mm}^{3}$ \\
2020 & Postoperative & $145 \mathrm{~mm}$ & $761 \mathrm{~mm}^{2}$ & $13030 \mathrm{~mm}^{3}$ \\
\hline
\end{tabular}

Abbreviations: MCA, maximum constriction area. Source: Authors. 
Although no signs and symptoms of dysphagia, dyspnea, or medical conditions were reported or diagnosed, the patient's husband reported an increase in snoring, gasping, and choking episodes. Moreover, signs of excessive daytime sleepiness, morning headache, and psychosocial disorders were not reported. After discussing the patient's possible breathing risks, it was recommended that the patient should undergo surgical treatment. Surgical planning was based on the CTA, CBCT, and selective laser sintering model. Exams ascertained the extension and limits of osteoma, and the proximity of the blood vessels near the tumor bone mass. Considering the huge size and position of the bone mass, an extraoral approach by preauricular incision, together with posterior extension and submandibular incision, were performed. After dissection, bone mass resection and mandible reshaping were conducted by bur, saw, chisel, and piezosurgery osteotomies. The surgery was performed with no major complications.

At the 5-month postoperative follow-up, the patient described an improvement in her sensation of mandibular swelling, a better pronunciation of words, an absence of orofacial pain, and hoarseness. Clinical examination presented an improvement in facial harmony and a complete recovery of facial mimic. The postoperative CBCT illustrated a better UA morphology, observed by a trapezoidal pharyngeal wall shape on the axial view. In addition, an increased UA volume of $44 \%$ and a 5.5 times larger minimum axial area was also observed (Table 1). (Figure 2)

Figure 2. A: Preoperative color map in the upper airway and volume in $3 \mathrm{D}$ showing in black the constriction area $\left(0-100 \mathrm{~mm}^{3}\right)$. B: Postoperative color map and volume in 3D shows an increase in the upper airway, that is highlight in red $\left(100-200 \mathrm{~mm}^{3}\right)$.

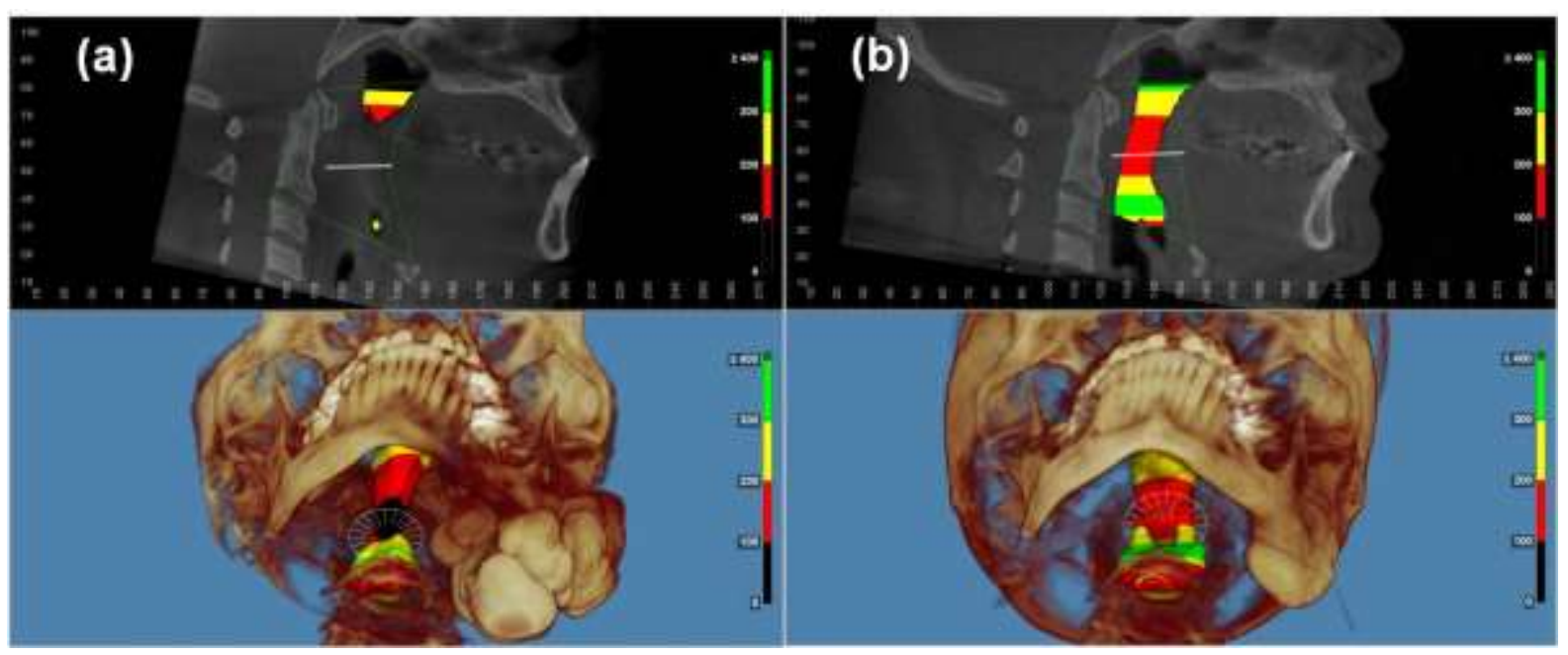

Source: Own authorship.

\section{Discussion}

Giant osteomas are benign lesions, with slow and progressive growth, and are larger than $3 \mathrm{~cm}$ (Fobe et al., 2002; Izci, 2005). Their growth is often relatively fast, as observed in our case, in which it presented a 2-year expansion on the left mandibular ramus of $48 \mathrm{~mm}$ in height and $37 \mathrm{~mm}$ in width. These osteomas are commonly associated with signs and symptoms, such as swelling, facial asymmetry, dysphagia, and respiratory disorders (Almeida \& de Oliveira Filho, 2011; Tarsitano \& Marchetti, 2013; Ata-Ali \& Ata-Ali, 2019) and occur not only due to expansive growth, but also due to their association with the anatomical location. Due to the interdependence between the hard and soft tissues, the medial growth of osteomas in different mandible regions can compromise the UA in the distinct oropharyngeal regions (Dos Santos et al., 2020). In the present case, the oropharynx and hypopharynx showed a significant decrease of $28 \%$ of its area.

Computed Tomography and CBCT are exams that are commonly used for qualitative and quantitative assessments of UA (Schendel et al., 2012; Bous et al., 2020). Specific types of software, such as Dolphin Imaging® (Dolphin Imaging \& 
Management Solutions, Chatsworth, CA), allow for an accurate reproduction of UA morphology (Dos Santos et al., 2020; Bous et al., 2020). These exams also provide the ability to quantify the impairment that a giant osteoma can cause in the airway through two-dimensional (2D) and three-dimensional (3D) evaluations. Mean values for MCA $\left(141.9 \mathrm{~mm}^{2}\right)$ and volume $\left(13210 \mathrm{~mm}^{3}\right)$ are related to patients who do not have respiratory deficiency and facial dentoskeletal deformities. When present, such as in retrognathic patients with MCA values below $52 \mathrm{~mm}^{2}$, this lesion can lead to the development of signs and symptoms related to the Obstructive Sleep Apnea Syndrome (SAOS) (Schendel et al., 2012). Surprisingly, in the present case, the patient had an MCA of $26 \mathrm{~mm}^{2}$, with no signs and symptoms of dysphagia, dyspnea, excessive daytime sleepiness, morning headache, and psychosocial disorders, reporting only exacerbated snoring as symptoms.

Treatment methods documented in the literature for the giant osteoma can be divided into conservative management14 and surgical approaches (Tarsitano \& Marchetti, 2013; Kerckhaert et al., 2005). The first is a possible option when the giant osteoma's anatomical location causes no functional impairment (Ata-Ali \& Ata-ali, 2019) or the facial asymmetry causes no patient concerns. However, in cases that present signs and symptoms of respiratory deficiency, surgical intervention is mandatory (Tarsitano \& Marchetti, 2013; Kerckhaert et al., 2005. The purpose of the surgical approach is to maintain UA patency (Tarsitano \& Marchetti, 2013). In this sense, the surgeon must have precise knowledge about important constriction areas due to the growth in the osteoma pathology. In the present case, late signs of respiratory dysfunction, such as the assessment of UA morphology, allowed us to highlight the maximum constriction areas, denoting the need for surgical treatment through there section of the giant osteoma along the medial mandible. Results from the surgical approach showed an increase of $44 \%$ in the total UA volume, as well as addition of $119 \mathrm{~mm}^{2}$ in the MCA.

\section{Final Considerations}

At the present moment, to the best of our knowledge, this is the first case report that performed a 3D assessment of UA in the treatment planning for giant osteoma surgery. The use of such tools as the CT and software aids medical professionals in assessing the airway as a whole, thus allowing for surgical planning and intervention in order to achieve UA maintenance in Gigantiform Osteoma treatment. Our patient continues in follow-up to assess the stability and maintenance of the airway. To date, the result has been maintained and the patient has not reported any complaints. Therefore we expect that more surgeons being careful and use of this tools to do a correct preoperative assessment.

\section{References}

Almeida, L. E., \& de Oliveira Filho, M. A. (2011). Giant mandibular condyle osteoma. The Journal of craniofacial surgery, $22(3)$, 1147-1149. https://doi.org/10.1097/SCS.0b013e318210baee

Ata-Ali, J., \& Ata-Ali, F. (2019). Giant peripheral osteoma of the mandible simulating a parotid gland tumor. Brazilian journal of otorhinolaryngology, 85(3), 393-395. https://doi.org/10.1016/j.bjorl.2016.03.004

Bous, R. M., Shah, P., Elnaghy, R., Elshebiny, T., \& Valiathan, M. (2020). Comparison of the Pharyngeal Airway Volume Between Patients With Ectodermal Dysplasia and Unaffected Controls: A Cone-Beam Computed Tomography Study. Journal of oral and maxillofacial surgery: official journal of the American Association of Oral and Maxillofacial Surgeons, 78(9), 1629.e1-1629.e9. https://doi.org/10.1016/j.joms.2020.04.014

Bodner, L., Gatot, A., Sion-Vardy, N., \& Fliss, D. M. (1998). Peripheral osteoma of the mandibular ascending ramus. Journal of oral and maxillofacial surgery: official journal of the American Association of Oral and Maxillofacial Surgeons, 56(12), 1446-1449. https://doi.org/10.1016/s0278-2391(98)90414-1

Cutilli, B. J., \& Quinn, P. D. (1992). Traumatically induced peripheral osteoma. Report of a case. Oral surgery, oral medicine, and oral pathology, 73(6), 667669. https://doi.org/10.1016/0030-4220(92)90006-c

Dos Santos, L. F., Albright, D. A., Dutra, V., Bhamidipalli, S. S., Stewart, K. T., \& Polido, W. D. (2020). Is There a Correlation Between Airway Volume and Maximum Constriction Area Location in Different Dentofacial Deformities?. Journal of oral and maxillofacial surgery: official journal of the American Association of Oral and Maxillofacial Surgeons, 78(8), 1415.e1-1415.e10. https://doi.org/10.1016/j.joms.2020.03.024

Fobe, L. P., Melo, E. C., Cannone, L. F., \& Fobe, J. L. (2002). Cirurgia de osteoma de seio frontal [Surgery of frontal sinus osteoma]. Arquivos de neuropsiquiatria, 60(1), 101-105. https://doi.org/10.1590/s0004-282x2002000100018 
Research, Society and Development, v. 10, n. 6, e5710615424, 2021

(CC BY 4.0) | ISSN 2525-3409 | DOI: http://dx.doi.org/10.33448/rsd-v10i6.15424

Hitchin, A. D., \& White, J. W. (1955). Central osteoma of the mandible. Oral surgery, oral medicine, and oral pathology, 8(7), 694-697. https://doi.org/10.1016/0030-4220(55)90031-1

Izci Y. (2005). Management of the large cranial osteoma: experience with 13 adult patients. Acta neurochirurgica, 147(11), 1151-1155. https://doi.org/10.1007/s00701-005-0605-4

Kerckhaert, A., Wolvius, E., van der Wal, K., \& Oosterhuis, J. W. (2005). A giant osteoma of the mandible: case report. Journal of cranio-maxillo-facial surgery: official publication of the European Association for Cranio-Maxillo-Facial Surgery, 33(4), 282-285. https://doi.org/10.1016/j.jcms.2005.03.001

Lekas, M. D., Sayegh, R., \& Finkelstein, S. D. (1997). Osteoma of the base of the tongue. Ear, nose, \& throat journal, 76(11), 827-828.

Ma'luf, R. N., Ghazi, N. G., Zein, W. M., Gedeon, G. A., \& Hadi, U. M. (2003). Orbital osteoma arising adjacent to a foreign body. Ophthalmic plastic and reconstructive surgery, 19(4), 327-330. https://doi.org/10.1097/01.IOP.0000075021.85888.6E

Neville, B. W.; Damm, D. D., Allen, C. M. \& Bouquot, J. E. (2009). Oral and Maxillofacial Pathology. 3rd ed. St. Louis, MO, Saunders Elsevier, pp. 652653.

Pereira, A. S., Shitsuka, D. M., Parreira, F. J. \& Shitsuka, R. (2018). Metodologia da pesquisa científica. UFSM.

Regezi, J. A.; Sciubba, J. J. \& Jordan, R. C. K. (2003). Oral Pathology: Clinical Pathologic. Correlations. 4th ed. St. Louis, MO, WB Saunders, pp. 296-297.

Sadeghi, H. M., Shamloo, N., Taghavi, N., Safi, Y., Aghdashi, F., \& Ismaeilnejad, M. (2015). Giant Osteoma of Mandible Causing Dyspnea: A Rare Case Presentation and Review of the Literature. Journal of maxillofacial and oral surgery, 14(3), 836-840. https://doi.org/10.1007/s12663-014-0717-6

Sayan, N. B., Uçok, C., Karasu, H. A., \& Günhan, O. (2002). Peripheral osteoma of the oral and maxillofacial region: a study of 35 new cases. Journal of oral and maxillofacial surgery: official journal of the American Association of Oral and Maxillofacial Surgeons, 60(11), 1299-1301. https://doi.org/10.1053/joms.2002.35727

Schendel, S. A., Jacobson, R., \& Khalessi, S. (2012). Airway growth and development: a computerized 3-dimensional analysis. Journal of oral and maxillofacial surgery: official journal of the American Association of Oral and Maxillofacial Surgeons, 70(9), 2174-2183. https://doi.org/10.1016/j.joms.2011.10.013

Tarsitano, A., \& Marchetti, C. (2013). Unusual presentation of obstructive sleep apnoea syndrome due to a giant mandible oste oma: case report and literature review. Acta otorhinolaryngologica Italica : organo ufficiale della Societa italiana di otorinolaringologia e chirurgia cervico-facciale, 33(1), 63-66. 